\title{
IfIISGUCDERGI.ORG
}

"İȘ, GÜC̣" ENDÜSTRi ilLișKiLERI VE INSAN KAYNAKLARI DERGISi

"IS, GUC" INDUSTRIAL RELATIONS AND HUMAN RESOURCES JOURNAL

\section{Türkiye'de Beşeri Sermaye Harcamaları ve İnsani Gelişmişlik}

\author{
Şadan Çalışkan \\ Yard.Doç.Dr., Uşak Üniversitesi, İ̈BF, İktisat Bölümü
}

Ocak/Jaunary 2010, Cilt/Vol: 12, Sayı/Num: 1, Page: 7-28

ISSN: 1303-2860, DOI: 10.4026/1303-2860.2010.135.x

Makalenin on-line kopyasına erişmek için:

http://www.isgucdergi.org/?p=makale\&id=384\&cilt=12\&sayi=1\&yil=2010

To reach the on-line copy of article:

http://www.isguc.org/?p=article\&id=384\&vol=12\&num=1\&year=2010

Makale İçin İletişim/Correspondence to: 
(C) 2000- 2010

"İşGüç" Endüstri İlişkileri ve İnsan Kaynakları Dergisi

"İşGüç" Industrial Relations and Human Resources Journal

Ocak/Jaunary 2010, Cilt/Vol: 12, Say1/Num: 1

ISSN: 1303-2860, DOI: 10.4026/1303-2860.2010.135.x

Editör/Editor-in-Chief

Aşkm Keser (Kocaeli University)

Editör Yardımcıları/Co-Editors

K.Ahmet Sevimli (Uludă̆ University)

Gözde Yılmaz (Kocaeli University)

Uygulama/Design

Yusuf Budak (Kocaeli Universtiy)

\author{
Yayin Kurulu / Publishing Committee \\ Dr.Zerrin Firat (Uludăg University) \\ Doç.Dr.Aşkın Keser (Kocaeli University) \\ Prof.Dr.Ahmet Selamoğlu (Kocaeli University) \\ Yrd.Doç.Dr.Ahmet Sevimli (Uludağ University) \\ Yrd.Doç.Dr.Abdulkadir Şenkal (Kocaeli University) \\ Yrd.Doç.Dr.Gözde Yilmaz (Kocaeli University) \\ Dr.Memet Zencirkıran (Uludă̆ University)
}

Uluslararası Danışma Kurulu / International Advisory Board

Prof.Dr.Ronald Burke (York University-Kanada)

Assoc.Prof.Dr.Glenn Dawes (James Cook University-Avustralya)

Prof.Dr.Jan Dul (Erasmus University-Hollanda)

Prof.Dr.Alev Efendioğlu (University of San Francisco-ABD)

Prof.Dr.Adrian Furnham (University College London-İngiltere)

Prof.Dr.Alan Geare (University of Otago- Yeni Zellanda)

Prof.Dr. Ricky Griffin (TAMU-Texas AEM University-ABD)

Assoc. Prof. Dr. Diana Lipinskiene (Kaunos University-Litvanya)

Prof.Dr.George Manning (Northern Kentucky University-ABD)

Prof. Dr. William (L.) Murray (University of San Francisco-ABD)

Prof.Dr.Mustafa Özbilgin (University of East Anglia-UK)

Assoc. Prof. Owen Stanley (James Cook University-Avustralya)

Prof.Dr.Işık Urla Zeytinoğlu (McMaster University-Kanada)

Danışma Kurulu / National Advisory Board

Prof.Dr.Yusuf Alper (Uludağ University)

Prof.Dr.Veysel Bozkurt (Uludağ University)

Prof.Dr.Toker Dereli (Işık University)

Prof.Dr.Nihat Erdoğmuş (Kocaeli University)

Prof.Dr.Ahmet Makal (Ankara University)

Prof.Dr.Ahmet Selamoğlu (Kocaeli University)

Prof.Dr.Nadir Suğur (Anadolu University)

Prof.Dr.Nursel Telman (Maltepe University)

Prof.Dr.Cavide Uyargil (İstanbul University)

Prof.Dr.Engin Yildırım (Sakarya University)

Doç.Dr.Arzu Wasti (Sabancı University)

Dergide yayınlanan yazılardaki görüşler ve bu konudaki sorumluluk yazarlarma aittir.

Yayınlanan eserlerde yer alan tüm içerik kaynak gösterilmeden kullanılamaz.

All the opinions written in articles are under responsibilities of the outhors.

None of the contents published can't be used without being cited. 


\title{
Türkiye'de Beşeri Sermaye Harcamaları ve İnsani Gelişmişlik
}

\author{
Şadan Çalışkan \\ Yard.Doç.Dr., Uşak Üniversitesi, İIBF, İktisat Bölümü
}

\begin{abstract}
Özet:
Bu çalışmada, Türkiye'de beşeri sermayenin temel iki bileşeni olan eğitim ve sağllk için yapılan harcamaların analizi amaç edinilmiştir. Ayrıca, Birleşmiş Milletler Kalkınma Programı insani gelişme raporlarında insani gelişmişliğin ïç temel kriteri olarak kabul edilen; eğitim, yaşam beklentisi ve gelir endeksleri açısından Türkiye'nin durumu ele alınmıştır. Türkiye'de eğitim ve sağlık harcamalarının gerek kişi başına miktarı, gerekse gayri safi yurtiçi hâsılaya oranı, gelişmiş̧ ülkelerle karşılaştırıldığında yeterli değildir. Harcamalardaki yetersizliğin de bir sonucu olarak, insani gelişmişliğin özellikle eğitim ve sağllk boyutuna ilişkin göstergelerinde önemli sıkıntılar bulunmaktadır. Kamu ve özel kesimin eğitim ve sağlık alanına daha fazla kaynak ayırması, Türkiye'nin insani gelişmişlik seviyesinin yükseltilmesine önemli katkılar sağlayacaktır.
\end{abstract}

Anahtar Kelimeler: Beşeri sermaye, eğitim, săğlk, beşeri sermaye harcamaları, insani gelişme.

\begin{abstract}
:
The purpose of this paper is to analyze two basic elements of human capital in Turkey: education and health expenditures. In addition, Turkey's status against three indexes (namely education, life expectancy, and income) which are accepted as the basic criteria for level of human development as mentioned in United Nations Development Program human development reports. Neither per capita figures of education and health expenses nor their share in gross domestic product are at a desirable level when compared to the figures in developed countries. As a result of this, health and education related indicators of human development level in particular are ringing the alarm bells. If public and private sectors allocate more resources to education and health, essential contribution will be made to elevating the human development in Turkey to a higher level.
\end{abstract}




\section{GiRiş}

Türkiye'nin sahip olduğu genç nüfus, ekonomik gelişme sürecinde önemli bir avantaj oluşturmaktadır. Bu avantajın etkin bir şekilde kullanılması; büyük ölçüde beșeri sermayenin en önemli iki bileşeni olan eğitim ve sağlık alanına yapılacak yatırımlara bağlıdır. Eğitim ve sağlığa yapılacak yatırımlarla ülke nüfusunun beşeri sermaye donamının artırılması; ekonomik gelişmeyi hızlandıracağ ${ }_{1}$ gibi küresel rekabette de önemli katkılar sağlayacaktır.

Bilginin giderek artan bir öneme sahip olması, bilginin elde edilmesine, dağıtılmasına ve kullanılmasına yönelik yatırımların artırılmasını gerektirmektedir. Bu noktada, bireylerin bilgi, beceri ve yeteneklerinin, dolayısıyla niteliklerinin iyileştirilmesine yönelik olarak yapılan "beşeri sermaye" yatırımlarının, özellikle eğitim yatırımlarının önemi artmaktadır (Altay ve Pazarlıoğlu, 2007: 96). Ekonomik yapının hızlı ve köklü değişikliklere uğradığ 1 , mesleki ve teknolojik değişimlerin hız kazandığı dünyamızda bir ülkenin küresel rekabette varolabilmesi, büyük ölçüde işgücünün eğitim düzeyine bağlıdır (Education at A Glance, 2004: 1). Artan küresel rekabet ortamında firmalar işçilerinden geçmişte olduğundan daha farklı ve yeni türden beceriler istemektedirler (Vorkink, 2005: 3). Bu süreçte, bir ülkenin uzun dönem ekonomik performansı, eğitim sisteminin ekonominin gereksinim duyduğu becerilerle donatılmış nitelikli insan gücünü yetiștirmedeki başarısına bağlıdır. Eğitim seviyesinin yükselmesi, yeni teknolojileri geliştirme, takip etme ve benimseme kapasitesini geliştirerek te kalkınma çabalarına katkıda bulunur.

Beşeri sermayenin bir diğer önemli bileşeni olan sağlık durumu da insan gücü potansiyelinin etkin kullanıminda önemli rol oynar. Bireyin işteki verimliliği büyük ölçüde zihinsel ve bedensel sağlik durumu tarafından belirlendiğinden, beşeri sermayenin sağllk alanına yapılacak yatırımlar işgücünün verimliliğini artırarak ekonomik kalkınmayı olumlu etkiler. Bireysel açıdan sağlık duru- munun bozulması, çalışma yaşamının sekteye uğramasına ve ömür boyu çalışma süresinin kısalmasına, işteki verimliliğin düşmesine, dolayısıyla gelir kaybına neden olurken, ulusal düzeyde ekonomik büyümeyi olumsuz etkiler.

Eğitim ve sağlık, beşeri sermaye oluşumuna ayrı ayrı katkıda bulunmanın yanında, birbirlerini tamamlayarak ta beșeri sermayenin artırılmasına katkıda bulunurlar. Örneğin; eğitim seviyesi yükseldikçe insanlar sağllkları konusunda daha duyarlı davranırlar. Önleyici ve tedavi edici sağllk hizmetlerinden daha fazla yararlanırlar. Daha dengeli ve düzenli beslenmeye dikkat ederek sağllklarını korumaya çalışırlar. Diğer taraftan, sağlık durumu daha iyi olan bireyler eğitim hayatlarında daha başarılı olurlar. Sağlık durumu düzeldikçe hastalık nedeniyle okuldan ayrı geçen süreler azalır ve eğitimin etkinliği artar. Eğitimli anne babalar; çocuklarının eğitimi, beslenmesi ve sağlığ 1 konusunda daha bilinçli hareket ederler.

1990'lara kadar gelişmişliğin en önemli göstergesi olarak kişi başına gelir baz alınmaktaydi. Ancak, gelişmekte olan ülkelerin önemli bir kısmında ekonomik büyümenin getirilerinden toplumun geniş kitlelerinin yeterince yararlanamaması (Günsoy, 2005: 36-37) ve yoksulluğun giderek artması nedeniyle tek başına gelir kriterinin iyi bir gösterge olmadığı yönünde ortaya çıkan genel kabulden sonra; kiși başına gelir ile birlikte sağlık ve eğitim kriterleri gelişmişliğin göstergesi olarak kullanılmaya başlanılmıştır (Göçer ve Çırac1, 2003: 4). Bu gelişmelere paralel olarak, Birleşmiş Milletler Kalkınma Programı (UNDP) tarafından 1990 yılından itibaren "insani gelişme raporu" adını taşıyan raporlar yayınlanmaya başlanılmıştır.

\section{BEŞERI SERMAYE TEORISI}

Beşeri sermaye teorisi, bireylerin elde ettikleri kazançlar ile bilgi, tecrübe ve niteliklerini artırmak amacıyla yaptıkları "beşeri sermaye yatırımları" arasındaki ilişkiyi açıklamak üzere ortaya atılmıştır. Beşeri sermaye yatırımları, eğitim, beslenme ve sağlık 
başta olmak üzere işgücünün üretkenliğini etkileyen tüm faaliyetler için yapılan harcamalardan oluşmaktadır.

Beşeri sermaye teorisine göre; bir ülkenin gelişmesinde en önemli unsur, nitelikli insan gücüdür. Bir ekonominin istikrarlı ve yüksek büyüme hızına ulaşabilmesi; sahip olduğu üretim faktörlerinin -özellikle işgücünün- etkin kullanımına bağlıdır. İşgücünün etkin kullanımı ise; işgücünün eğitim, sağlık ve mesleki beceri açısından sahip olduğu donanıma yani beşeri sermaye düzeyine bağlıdır (Dahlin, 2002: 16). Beşeri sermaye teorisine göre, diğer üretim faktörlerinin verimliliği de büyük ölçüde beşeri sermaye tarafından belirlenmektedir.

Beşeri sermayenin önemini vurgulayan ilk iktisatçı Smith'dir. Smith, toplumun kazanılmış ve faydalı becerilerini sabit sermaye kavramı içine dahil ederek, bu nitelikleri kişinin ve toplumun servetinin bir parçası olarak kabul etmiştir. Smith, nitelikli emekle niteliksiz emek arasındaki gelir farkını bireyin kendisine yaptığı yatırımlara bağlamıştır (Doğan ve Şanlı, 2003: 176). Smith, "pahalı bir makineyle karşılaştırıldığında emek ve zaman harcanarak eğitilmiş bir insan, öğrendiği iş nedeniyle sıradan işçilere göre elde edeceği yüksek gelirle eğitiminin tüm masraflarını karşılayacaktır" diyerek, beşeri sermayenin önemine dikkat çekmiştir (Ar1soy ve Demir, 2001: 1). Smith'in nitelikli emeğin daha yüksek gelir elde etmesine vurgu yapmasindan sonra, bireylerin niteliklerini artıran bir faktör olarak eğitim, sosyal ve ekonomik yaşamda eşitliği sağlamaya yönelik bir faaliyet olarak kabul edilmiştir.

Smith'le birlikte Mill ve Marshall gibi iktisatçılar da beşeri sermayenin önemine dikkat çekmekle birlikte, beşeri sermaye kavramının ön plana çıkması özellikle, Schultz (1961), Denison (1962 ve 1968), ve Becker'in (1962) çalışmalarından sonra olmuştur (Dura ve diğ., 2004:13). Bu çalışmalardan sonra ekonomi yazınında beşeri sermayenin bireysel getiriler ve ekonomik büyüme üzerindeki etkilerini konu alan çalışmalar yapılmıştır. Bilgi toplumuna geçiş sürecinde, geleneksel üretim faktörlerinin yanında gelişmeyi belirleyen önemli bir faktör olarak bilginin, dolayısıyla nitelikli işgücünün ön plana çıkması, beşeri sermaye konusuna ilgiyi artırmıştır (Doğan ve Şanlı, 2003:174).

"Beşeri sermaye" kavramı, ilk olarak Schultz tarafından kullanılmıştır. Schultz, beşeri sermayeyi, bir toplumun sahip olduğu, üretim sürecinde faydalı yeteneklerin toplamı olarak tanimlamaktadir (Shultz, 1968: 277). Schultz'a göre bireyler, sağlık hizmeti, örgün ve yaygın eğitimden yararlanma, işbaşında yetiştirme eğitimi ve daha iyi iş imkânı elde etmek amaciyla göç etme gibi nedenlerle harcama yaparak beşeri sermayelerine yat1rım yaparlar (Shultz, 1971: 36). Beşeri sermaye kavramı; bireylerin emek piyasasındaki getirilerini artıran, bilgi, beceri, tecrübe, sağllk durumu ile verimliliğini artıran diğer tüm nitelikleri kapsar. Teoriye göre; bireyin üretkenliğini artıran her türlü etkinlik, beşeri sermaye kavramı içinde değerlendirilir. Bu amaçla yapılan her türlü harcama da "beşeri sermaye yatırımı" olarak kabul edilir (Tural, 2002: 5).

1980'lerde içsel büyüme modellerinin gündeme gelmesiyle, beşeri sermaye ve ekonomik büyüme ilişkisi yeniden popüler olmuştur. İçsel büyüme modellerinde, beşeri sermaye, fiziki sermayeye ilave olarak ekonomik büyümenin önemli bir bileşeni olarak kabul edilmiştir (Çakmak ve Gümüş, 2004: $60)$. Bu bağlamda, işgücünün kalitesini art1ran faktörler olarak eğitim ve sağlık durumundaki iyileşmelerin ekonomik büyümeyi hızlandıracağı kabul edilmiştir (Kar ve Taban, 2005: 2-3).

Lucas'ın içsel büyüme modeline göre beşeri sermaye iki farklı kanaldan büyümeye etki etmektedir: Bunlardan ilki olan "içsel etkiler" bireylerin beceri düzeyleri ile ilgilidir ve sadece ilgili bireylerin verimliliğini etkilemektedir. Dolayısıyla, eğitim ve diğer öğrenme araçlarıyla artan beceriler bireyleri daha verimli kılmaktadır. İkinci etki ise "dışsal etki" olarak adlandırılmakta ve bireyler arasındaki bilgi paylaşımından kaynaklanan dış- 
sallıkları temsil etmektedir (Saygılı ve diğ., 2005: 129-130).

\subsection{Beşeri Sermaye Yatırımları İçinde Eğitimin Yeri}

Beşeri sermaye yatırımları temel olarak üç alanı kapsar; eğitim, sağlık ve beslenme. Ancak bu üçü içinde, beşeri sermayenin oluşumunda etkili olan en önemli faktör eğitimdir. Beşeri sermaye teorisi, eğitimi beşeri sermayenin temel kaynağı ve bireyin ömür boyu gelirini pozitif ve doğrudan etkileyen en etkili faktör olarak kabul eder. Eğitim, sürdürülebilir ekonomik büyümeyi gerçekleştirmek için gerekli olan nitelikli insan gücünü yetiştirerek büyüme sürecinde önemli rol oynar (Nasir and Nazli, 2000: 1).

Günümüzde ülkelerin ekonomik ve ticari alandaki üstünlükleri, önemli ölçüde teknoloji yaratma ve teknoloji transferini kolaylaştırma ile bunları ekonomik ve toplumsal faydaya dönüştürme konusundaki başarılarına bağlıdır. Gelişmekte olan ülkelerde beşeri sermaye donanımının yükselmesi gelişmiş ülkelerden teknoloji transferini kolaylaştırarak büyüme hızının yükselmesini sağlamaktadır. Bu süreçte en önemli kaynak "bilgi"dir (Arısoy ve Demir, 2001: 1). Eğitim, bilgi üretmenin, dağıtmanın ve kullanmanın en etkili aracıdır. Eğitim düzeyinin yükseltilmesi; kaynakların etkin kullanımını sağlayarak verimliliğin artırılmasını, orta ve uzun dönemde gelirin daha adil dağıtılmasını ve istihdamın artırılmasını sağlar (Altay, 2005).

Eğitim, bireylere iş yaşamında kullanabilecekleri bilgi ve beceriler kazandırarak emek piyasasındaki verimliliklerini artırır. Ayrıca, eğitim sürecini tamamlayan bireyler, meslekleri ile ilgili stajlar yaparak ya da ilave eğitimler alarak eğitim sürecinde elde ettikleri bilgi ve becerileri artırabilirler (Borghans ve Heijke, 2005: 133). Bireysel açıdan verimlilik artışlarına, dolayısıyla kişisel kazançlarda artışa neden olan beşeri sermaye yatırımları aynı zamanda ülke ekonomisinin sahip olduğu beşeri sermaye miktarını artırarak milli gelir seviyesinin yükselmesine katkı sağlar.
Daha yüksek eğitim, bireyin daha fazla gelir etmesi, daha az suç oranı, daha demokratik tutum ve daha etkin yönetime katılma, daha iyi bireysel sağlık gibi pek çok olumlu etkiye neden olur. Eğitim bu özelliği ile sadece bireysel değil, toplumsal yararlar da sağlar (Eriş, 2005). Yoksullukla mücadele ve gelir dağılımın daha eşitlikçi bir yapıya kavuşturulmasında önemli rol oynar. Eğitim, demokratikleşme, katılımcılık, insan hakları ve sosyal uyum gibi çağdaş toplumsal değerlerin yerleşmesinde ve politik istikrarın tesisinde de büyük önem taşır (Saygılı ve diğ., 2005: 131).

Bir toplumun eğitim standartlarının ekonomik değişkenler üzerindeki etkilerini araşttran geniş bir literatür bulunmaktadır. Örneğin; Denison "The Source of Economic Growth in The United States" adli eserinde, Cobb Douglas üretim fonksiyonunu kullanarak eğitim ile ekonomik büyüme arasındaki ilişkiyi ortaya koymuştur. Denison "artık yaklaşımı" olarak tanımlanan bu yöntemle, GSYİH'da meydana gelen değişimin ne kadarlık kısmının işgücünün niteliğinden kaynaklandığını açıklamaya çalışmıştır. Denison, 1929 ile 1957 yılları arasında ABD'nin ekonomik büyümesinin \%23'ünün eğitim ile açıklanabileceği sonucunu elde etmiştir (Denison, 1962). Eğitim harcamalarını gelişmekte olan ülkelerin üretim kapasitesini artıran ve fiziki sermaye yatırımlarının verimliliğini artıran bir araç olarak gören Psacharopoulos, gelişmekte olan ülkelerin büyümesini sınırlandıran en önemli faktör olarak beşeri sermaye yetersizliğini kabul etmektedir (Doğan ve Şanlı, 2003: 189).

Mincer, eğitim seviyesinin yükselmesinin işsizlik riskini azalttığını ortaya koymuştur (Mincer, 1991: 1). Nickel ise eğitimin sadece işsizlik riskini azaltmadığını, işsiz kalma süresini de kısalttığını, bu nedenle eğitimin getirileri hesaplanırken bu etkinin de dikkate alınmasını belirtmektedir (Brunello, 2001: 1).

Avrupa Birliği (AB), 2005'in başlarında kabul ettiği İstihdam Politikası Kılavuzunda $\mathrm{AB}^{\prime}$ nin ekonomik büyümesinin işgücünün daha yüksek becerilere sahip olmasına bağlı olduğu ve eğitim düzeyini iyileştirmenin iş- 
gücü becerilerini iyileştirmede en iyi yol olduğunu kabul etmiştir (Vorkink, 2005: 4).

\subsection{Beşeri Sermaye Yatırımları İçinde Să̆lı̆̆ın Yeri}

Sağlık, insanoğlunun sahip olduğu en önemli varlığıdır. İnsanın kapasitesini tam olarak kullanabilmesi ancak sağlıklı olması ile mümkündür. Fiziksel ya da zihinsel sağlik problemi yaşayan bireyler, iş yaşamlarında tam olarak verimli olamadıkları gibi günlük yaşamlarında da önemli sıkıntılarla karşılaşmaktadırlar. Bu nedenle, sağlıklı ve uzun yaşama arzusu bütün insanların ortak dileğidir. Sağlık ile ekonomik getiriler arasındaki aynı yönlü ilişki, bu dileğin ekonomik temelini oluşturmaktadır (Aguayo-Rico, 2005: 1).

Beşeri sermayenin asıl kaynağını eğitim oluşturmakla birlikte, toplumun sağlık düzeyi de beşeri sermayeyi besleyen ve gelişmesine katkıda bulunan önemli bir unsurdur. Schultz, sağlık hizmetlerini, bireyin çalışma yeteneğini koruyup geliştirmesi ve ileriki yıllarda ortaya çıkması muhtemel bir kısım hastalıkları önleyerek verimliliğini artırmasından dolayı, beşeri sermaye yatırımı olarak değerlendirmektedir (Taban, 2006: 35).

Mikro iktisadi analizde eğitimle birlikte işçi sağlığının, işçinin verimlilik ve ücretini etkileyen önemli bir etken olduğu kabul edilir. Yapılan ampirik çalışmalarda eğitim ve sağlık durumlarındaki farklılıkların ülkeler arasında işçi verimliliğini etkileyen önemli birer faktör oldukları sonuna ulaşılmıştır. Sağlık, hem işçilerin bilişsel kavrayış ve muhakeme kabiliyeti gibi zihinsel yeteneklerini artırarak, hem de dayanıklılık ve güçlülük gibi fiziki kapasitelerinde artışlar sağlayarak verimlilik artışlarına neden olur. Bu nedenle, gerek vasıflı gerekse vasıfsız işçilerin verimliliği ile sağlık durumları arasında pozitif ilişki olduğu kabul edilmektedir (Bloom ve diğ., 2002: i-1).

Sağlık durumu daha iyi olan işçilerin verimlilikleri diğerlerine göre daha yüksek olduğundan, üretim sürecindeki payları olan ücretleri de daha yüksektir. Yapılan çalışmalarda çocukluk ve gençlikte sağlık ile beslenmeye yapılan yatırımların yetişkinlikte ücret artışı olarak ortaya çıktığı ortaya konulmuştur (Bloom ve diğ., 2004: 11). Sağlık ve kişisel gelir arasındaki bağ iki yönlüdür; gelir artışı sağlığı, sağlık durumundaki iyileşme de geliri olumlu etkilemektedir (Bloom ve Canning, 1999: 2).

Eğitimle sağlık arasında da iki yönlü ilişki vardır. Sağlık durumunun iyileşmesi eğitimin etkinliğini artırırken, eğitim seviyesinin yükselmesi de sağlık durumunu olumlu etkilemektedir (Webber, 2002: 1634). Grosman (1972) ve Bloom ve Canning (2000) sağlıklı bireylerin bilgiyi kavrama ve uygulama becerilerinin daha yüksek olduğu, dolayısıyla verimliliklerinin daha yüksek olduğunu iddia ederler (Aguayo-Rico, 2005: 1).

Gelir ve sağlık arasında makro ekonomik anlamda da pozitif ilişki vardır. Sağlıkla ekonomik büyüme arasındaki ilişki üzerine yaptığı çalışmalarla, Nobel ödülü kazanan Fogel, İngiltere'de beslenme ve sağlık koşullarındaki gelişmenin büyüme üzerindeki etkilerini araştırdığı çalışmada; 200 yılı aşan inceleme döneminde ekonomik büyümenin üçte birlik kısmının beslenme ve sağlık koşullarındaki iyileşmeden kaynaklandığı sonucuna ulaşmıştır. Fogel'i takiben yapılan çalışmalarda da sağlığın ekonomik büyüme üzerindeki önemini gösteren bulgular elde edilmiştir (Mayer, 2000: 2). Örneğin; Barro (1996), ortalama yaşam süresinin büyüme üzerinde pozitif etkiye sahip olduğunu ortaya koymuştur (Mayer, 2000: 2). Bloom ve diğerleri de (2001) 104 ülkenin 1960-1990 dönemine ait verilerinin kullanarak yaptıkları çalışmada yaşam süresinin uzamasının büyümeyi olumlu etkilediği sonucuna ulaşmişlardır (Bloom ve diğ., 2001). Taban da Türkiye'de sağlık ve ekonomik büyüme arasındaki nedensellik ilişkisini araştırdığı çalışmada reel gayri safi yurtiçi hâsıla (GSYİH) ile sağlık göstergeleri arasında çift yönlü nedensellik ilişkisi bulunduğu sonucuna ulaşmiştır (Taban, 2006: 32).

Sorkin (1977) sağlığın ekonomik büyüme üzerine etkilerini konu alan çalışmasında; 
sağl1k şartlarındaki iyileşmenin -özellikle ölüm oranlarındaki düşüşün- 20. yüzyılın başlarında ekonomik gelişme üzerinde önemli etkisi olduğu sonucuna ulaşmıştır. Sorkin, gelişmekte olan ülkelerde sağlık koşullarındaki iyileşmenin ekonomik büyüme üzerindeki etkisinin gelişmiş ülkelerde göre fazla olduğunu iddia ederek, gelişmekte olan ülkelerde sağlık yatırımlarına önem verilmesine işaret etmektedir (Aguayo-Rico, 2005: 1).

Yoksul insanların sağlık durumlarının iyileştirilmesi ve ortalama yaşam süresinin uzatılması ekonomik gelişmenin temel amaçlarından birisidir. Sağlık durumunun iyileştirilmesi aynı zamanda yoksullukla mücadelenin de bir aracıdır (Weil, 2007: 1265). Gelişmekte olan ülkelerde üretim teknikleri ağırlıklı olarak emeğin bedensel gücüne dayalı olduğundan, bu ülkelerde emek sahiplerinin beden sağlığı işgücüne katılım oranı ve üretim sürecindeki verimliliklerini etkileyen önemli bir unsur olarak ortaya çımaktadır (Suhrcke ve diğ., 2006: 995).

Ülkelerin gelişmişlik düzeyi yükseldikçe sağlık durumları da iyileşmektedir. Daha yüksek gelir seviyesine sahip ülkelerde daha besleyici ve sağlıklı gıdalara ulaşmanın mümkün olması, daha temiz su kaynaklarına sahip olunmas1, koruyucu ve tedavi edici sağlık hizmetlerinin daha kaliteli sunulmasının toplumun sağlık durumunun iyileşmesi ile sonuçlanması beklenir (Bloom ve di ğ., 2002: 2).

\section{Türkiye'de Eğitim Harcamaları}

Bir ülkede eğitim için GSYİH'dan ayrılan pay, o ülkede insana dolayısıyla beşeri sermayeye verilen önemin göstergesi olarak kabul edilmektedir. Tablo 1'de seçilmiş Ekonomik İşbirliği ve Kalkınma Teşkilatı (OECD) ülkelerinde eğitim harcamaları ile ilgili temel göstergeler yer almaktadır. OECD bölgesinde eğitime GSYİH'dan en yüksek pay ayıran ülke \%8 ile İzlanda'dır. İzlanda'yı Amerika Birleşik Devletleri (ABD), Danimarka ve Kore izlemektedir. OECD bölgesinde eğitime en düşük payı ayıran ülke Türkiye'dir. Türkiye'yi Yuna- nistan ve Slovakya izlemektedir. Türkiye eğitime $\% 4,1$ pay ayırırken, Yunanistan $\% 4,2$ ve Slovakya $\% 4,4$ pay ayırmaktadır. OECD bölgesinde, ortalama olarak eğitime GSYİH'dan \%5,8 pay ayrılmaktadır.

OECD bölgesinde, eğitim harcamalarının \%86's1 kamu, \%14'ü özel kesim tarafından finanse edilmektedir. OECD ülkeleri arasında eğitim harcamaları içinde özel kesimin pay1nın en yüksek olduğu üç ülke sirasıyla \%40 ile Kore, \%33 ile ABD ve \%31 ile Japonya'dır. OECD ülkeleri arasında eğitim harcamaları içinde kamunun payının en yüksek olduğu ülkeler ise; \%98 ile Finlandiya, \%97 ile İsveç ve \%96 ile Belçika'dır. Türkiye'de eğitim harcamalarının \%93'ü kamu, \%7'si özel kesim tarafından finanse edilmektedir.

Türkiye'de toplam kamu eğitim harcamaları içinde ilk ve orta öğretimin payı \%76, yüksek öğretimin payı \%24'tür. Özel kesimin eğitimin harcamaları içinde ilk ve orta öğretimin payı \%67, yüksek öğretimin payı \%33'tür. Kamu ve özel kesim eğitim harcamalarının toplamı dikkate alındığında ise Türkiye'de eğitim harcamalarının \%76'sı ilk ve orta öğretim, \%24 ise yüksek öğretim için ayrılmaktadır (Education at a Glance 2008).

Ülkeler arasında eğitim harcamaları karşılaştırılırken kullanılan göstergelerden birisi de eğitim kademelerine göre öğrenci başına yapılan harcama miktarıdır. Bu açıdan bakıldığında da Türkiye'nin durumu pek iç açıcı değildir. Türkiye'de öğrenci başına ilköğretimde 869, orta öğretimde 1428 yüksek öğretimde 3428 dolar harcama yapılmaktadır. Türkiye bu harcama miktarları ile tüm eğitim kademelerinde OECD ülkeleri arasında öğrenci başına en az harcama yapan ülkedir. Lüksemburg ilköğretimde 14079, ortaöğretimde 18875 dolarla öğrenci başına en çok harcama yapan ülkedir. OECD ortalamas1 ilköğretimde 6252, orta öğretimde 7804 ve yüksek öğretimde 11512 dolardır.

Tablo 2'de, 1995 yılı baz alındığında eğitim kademelerine göre yıllar itibariyle eğitim harcamalarının gelişimi yer almaktadır. 1995 yılından 2004 yılına kadar tüm eğitim kademelerinde gerek OECD, gerekse Avrupa Bir- 
Tablo 1

Seçilmiş Ülkelerde Eğitim Harcamaları 2005

\begin{tabular}{|c|c|c|c|c|c|c|c|c|}
\hline \multirow[b]{2}{*}{ Ülkeler } & \multicolumn{3}{|c|}{ Eğitim Harcamaları / GSYİH } & \multicolumn{2}{|c|}{$\begin{array}{l}\text { Eğitim Harcamaları } \\
\text { İçinde Kamu ve } \\
\text { Özel Kesimin Payı }\end{array}$} & \multicolumn{3}{|c|}{$\begin{array}{c}\text { Öğrenci Başına Yıllık Harcama } \\
\text { Tutarı, Dolar (Satın alma Gücü } \\
\text { Paritesine Göre) }\end{array}$} \\
\hline & Kamu & Özel & Toplam & Kamu & Özel & $\begin{array}{c}\text { İlk } \\
\text { Öğgretim }\end{array}$ & $\begin{array}{c}\text { Orta } \\
\text { Öğretim }\end{array}$ & $\begin{array}{l}\text { Yüksek } \\
\text { Öğretim }\end{array}$ \\
\hline Avustralya & 4,3 & 1,5 & 5,8 & 0,73 & 0,26 & 5992 & 8408 & 14579 \\
\hline Avusturya & 5,2 & 0,4 & 5,5 & 0,94 & 0,06 & 8259 & 9751 & 14775 \\
\hline Belçika & 5,8 & 0,3 & 6,0 & 0,96 & 0,04 & 6648 & 7731 & 11960 \\
\hline Çek Cumhuriyeti & 4,1 & 0,6 & 4,7 & 0,88 & 0,12 & 2812 & 4847 & 6649 \\
\hline Danimarka & 6,8 & 0,6 & 7,4 & 0,92 & 0,08 & 8513 & 9407 & 14959 \\
\hline Finlandiya & 5,9 & 0,1 & 6,0 & 0,98 & 0,02 & 5557 & 7324 & 12285 \\
\hline Fransa & 5,6 & 0,5 & 6,0 & 0,93 & 0,07 & 5365 & 8927 & 10995 \\
\hline Almanya & 4,2 & 0,9 & 5,1 & 0,82 & 0,18 & 5014 & 7636 & 12446 \\
\hline Yunanistan & 4,0 & 0,3 & 4,2 & 0,94 & 0,06 & 5146 & 8423 & 6130 \\
\hline Macaristan & 5,1 & 0,5 & 5,6 & 0,91 & 0,09 & 4438 & 3806 & 6244 \\
\hline İzlanda & 7,2 & 0,7 & 8,0 & 0,91 & 0,09 & 9254 & 8411 & 9474 \\
\hline İrlanda & 4,3 & 0,3 & 4,6 & 0,94 & 0,06 & 5732 & 7500 & 10468 \\
\hline İtalya & 4,3 & 0,4 & 4,7 & 0,90 & 0,09 & 6835 & 7648 & 8026 \\
\hline Japonya & 3,4 & 1,5 & 4,9 & 0,69 & 0,31 & 6744 & 7908 & 12326 \\
\hline Kore & 4,3 & 2,9 & 7,2 & 0,60 & 0,40 & 4691 & 6645 & 7606 \\
\hline Meksika & 5,3 & 1,2 & 6,5 & 0,81 & 0,19 & 1913 & 2180 & 6402 \\
\hline Hollanda & 4,6 & 0,4 & 5,0 & 0,92 & 0,08 & 6266 & 7741 & 13883 \\
\hline Yeni Zelanda & 5,2 & 1,4 & 6,7 & 0,78 & 0,22 & 4780 & 6278 & 10262 \\
\hline Polonya & 5,4 & 0,6 & 5,9 & 0,91 & 0,09 & 3312 & 3055 & 5593 \\
\hline Portekiz & 5,3 & 0,4 & 5,7 & 0,93 & 0,07 & 4871 & 6473 & 8787 \\
\hline Slovakya & 3,7 & 0,7 & 4,4 & 0,84 & 0,16 & 2806 & 2716 & 5783 \\
\hline İspanya & 4,1 & 0,5 & 4,6 & 0,89 & 0,11 & 5502 & 7211 & 10089 \\
\hline İsveç & 6,2 & 0,2 & 6,4 & 0,97 & 0,03 & 7532 & 8198 & 15946 \\
\hline Türkiye & 3,8 & 0,3 & 4,1 & 0,93 & 0,07 & 869 & 1428 & 3428 \\
\hline İngiltere & 5,0 & 1,3 & 6,3 & 0,80 & 0,20 & 6361 & 7167 & 13506 \\
\hline $\mathrm{ABD}$ & 4,8 & 2,3 & 7,1 & 0,67 & 0,33 & 9156 & 10390 & 24370 \\
\hline OECD Ortalaması & 5,0 & 0,8 & 5,8 & 0,86 & 0,14 & 6252 & 7804 & 11512 \\
\hline
\end{tabular}

\section{Kaynak:}

OECD in Figures 2008, ss.22-23;

StatLink: http:/ /dx.doi.org/10.1787/468064465655;

Education at a Glance 2008: http://www.oecd.org/edu/eag2008 
Tablo 2

Seçilmiş OECD Ülkelerinde Eğitim Kademesine Eğitim Harcamalarındaki Değişimler $(1995,2000,2004)$ (Değişim Endeksi, 1995=100, Sabit Fiyatlarla)

\begin{tabular}{|c|c|c|c|c|c|c|c|c|c|}
\hline \multirow{2}{*}{ Ülkeler } & \multicolumn{3}{|c|}{ Tüm Eğitim Kademeleri } & \multicolumn{3}{|c|}{ İlk ve Orta Öğretim } & \multicolumn{3}{|c|}{ Yüksek Öğretim } \\
\hline & 1995 & 2000 & 2004 & 1995 & 2000 & 2004 & 1995 & 2000 & 2004 \\
\hline Avustralya & 100 & 127 & 145 & 100 & 134 & 150 & 100 & 110 & 132 \\
\hline Avusturya & 100 & 103 & 108 & 100 & 106 & 108 & 100 & 102 & 126 \\
\hline Çek Cumhuriyeti & 100 & 89 & 116 & 100 & 86 & 111 & 100 & 99 & 145 \\
\hline Danimarka & 100 & 123 & 138 & 100 & 119 & 130 & 100 & 110 & 133 \\
\hline Finlandiya & 100 & 113 & 134 & 100 & 112 & 135 & 100 & 111 & 128 \\
\hline Yunanistan & 100 & 155 & 208 & 100 & 147 & 172 & 100 & 160 & 312 \\
\hline Macaristan & 100 & 111 & 150 & 100 & 100 & 142 & 100 & 135 & 159 \\
\hline İrlanda & 100 & 137 & 171 & 100 & 122 & 174 & 100 & 178 & 174 \\
\hline İtalya & 100 & 103 & 107 & 100 & 95 & 104 & 100 & 126 & 144 \\
\hline Japonya & 100 & 107 & 111 & 100 & 103 & 105 & 100 & 116 & 125 \\
\hline Meksika & 100 & 129 & 159 & 100 & 124 & 147 & 100 & 129 & 168 \\
\hline Hollanda & 100 & 115 & 134 & 100 & 119 & 143 & 100 & 106 & 115 \\
\hline Yeni Zelanda & 100 & 133 & 154 & 100 & 140 & 162 & 100 & 96 & 109 \\
\hline Norveç & 100 & 103 & 134 & 100 & 106 & 129 & 100 & 94 & 117 \\
\hline Polonya & 100 & 125 & 151 & 100 & 136 & 152 & 100 & 113 & 202 \\
\hline Portekiz & 100 & 130 & 136 & 100 & 132 & 133 & 100 & 136 & 143 \\
\hline Slovakya & 100 & 105 & 146 & 100 & 105 & 140 & 100 & 126 & 210 \\
\hline İspanya & 100 & 110 & 124 & 100 & 101 & 107 & 100 & 139 & 162 \\
\hline İsveç & 100 & 123 & 139 & 100 & 123 & 139 & 100 & 123 & 144 \\
\hline İsviçre & 100 & 106 & 116 & 100 & 100 & 113 & 100 & 136 & 176 \\
\hline Türkiye & 100 & 175 & 229 & 100 & 174 & 243 & 100 & 179 & 191 \\
\hline İngiltere & 100 & 112 & 139 & 100 & 115 & 149 & 100 & 102 & 122 \\
\hline ABD & 100 & 131 & 148 & 100 & 125 & 140 & 100 & 142 & 163 \\
\hline OECD Ortalaması & 100 & 119 & 142 & 100 & 117 & 139 & 100 & 124 & 155 \\
\hline AB19 Ortalaması & 100 & 117 & 138 & 100 & 114 & 134 & 100 & 124 & 158 \\
\hline
\end{tabular}

Kaynak: http://www.oecd.org/edu/eag2007

liği ülkelerinde eğitim harcamalarının arttığ görülmektedir. 1995 yılı başlangıç kabul edildiğinde sabit fiyatlarla eğitim harcamalarında en büyük artış Türkiye' de ortaya çıkmıştır. 2004 yılına gelindiğinde, 1995 yılında 100 kabul edilen endeks 229'a yükselmiştir. Türkiye'de kamu eğitim harcamalarında meydana çıkan bu artış önemli bir adım olmakla birlikte; halen öğrenci başına harcama miktarı ve GSYİH'dan ayrılan pay gelişmiş ülkeler seviyesine ulaşmamıştır. Bu dönemde eğitim harcamalarındaki en büyük artışın gerçekleştiği ikinci ülke 208 endeks değeri ile Yunanistan'dır. 1995-2004 döneminde endeksin en az artış gösterdiği ülkeler; İtalya, Avusturya ve Almanya'dır. Bu ülkelerde endeksin önemli bir gelişim göstermemesi, eğitim harcamalarının dönem 
başlangıcında da yüksek olmasının bir sonucudur.

Türkiye 1995 'ten 2004'e kadar olan dönemde, tüm eğitim kademelerinin toplamı için yapılan harcamalarda olduğu gibi ilk ve orta öğretim kademelerinde de en yüksek harcama artışı yaşanan ülkedir. 1995'te 100 olan ilk ve orta öğretim harcama endeksi 2004 yılında 243'ye yükselmiştir. Yüksek öğretim basamağında ise 1995-2004 döneminde en yüksek artış Yunanistan'da, en düşük artış ise Yeni Zelanda'da ortaya çıkmiştır. Türkiye'de 1995 yılında 100 olan endeks 2004 yılında 191'e yükselmiştir.

\section{Türkiye'de Sağlık Harcamaları}

Toplumun sağlık düzeyi ile ekonomik gelişmişlik arasında yakın bir ilişki vardır. Gelişmişlik düzeyi belirli bir aşamaya ulaşmış toplumlarda sağlık için ayrılan kaynaklar arttığ 1 gibi, bireylerin sağlik bilinci de yükselmektedir. Sağlık düzeyinin yükselmesi de artan verimlilik yoluyla ekonomik büyümeyi hızlandırmaktadır (Mazgit, 2002: 405). Sağlık hizmetleri, bireysel olarak en temel ihtiyaçlar arasında yer almasının yanında, kamusal hizmet bağlamında sosyal politikaların önemli ve vazgeçilmez bir unsurudur. Eğitim gibi yarı kamusal mallar arasında yer alan sağlık hizmetlerinin sunumunda temel sorumluluk devlete aittir. Bu nedenle, en azından temel seviyede sağlık hizmetlerinin finansmanının devlet tarafından karşılanması gerekmektedir.

Tablo 3'te OECD ülkelerinde sağlık harcamalarının genel görünümüne ilişkin bilgiler sunulmuştur. 2006 yılı verilerine göre OECD bölgesinde ortalama olarak GSYİH'nın $\% 8,9$ 'u sağlığa ayrılmaktadır. GSYİH'da sağlık harcamalarına ayrılan pay, ülkeler arasında önemli farklılıklar göstermektedir. OECD ülkeleri içinde sağlığa GSYİH'dan en yüksek pay ayıran ülke \%15,3 ile ABD'dir. ABD'yi, sırasıyla \%11,3 ile İsviçre ve \%11,1 ile Fransa takip etmektedir. Ülkelerin gelişmişlik düzeyi arttıkça sağlık için ayrılan payın arttığı görülmektedir.

Türkiye'de sağlık harcamaları için 1995 y1- lında GSYİH'dan \%3,4 pay ayrılırken, 2006 yılında bu oran \%5,7'ye yükselmiştir. Türkiye, 2000-2006 döneminde yıllık \%7,6 ile artış hızı ile, GSYİH'ya oran olarak sağlık harcamaları en hizlı artan Kore ve Slovakya'dan sonra üçüncü ülke olmasına rağmen OECD ülkeleri arasında GSYİH'dan sağlığa en düşük payı ayıran ülke konumundan kurtulamamıştır.

OECD ülkelerinin çoğunluğunda sağlık hizmetleri ağırlıklı olarak kamu tarafından finanse edilmektedir. OECD ortalamasina göre; sağlık hizmetlerinin \%73'ü kamu tarafından finanse edilmektedir. ABD ve Meksika dışındaki bütün ülkelerde sağlık harcamalarının büyük bölümünü kamu üstlenmektedir. Sağlık hizmetlerinin Meksika'da \%55,8'zi, ABD'de \%54,2'si özel kesim tarafından finanse edilmektedir. Türkiye'de ise sağlık hizmetlerinin \%71,4'ü kamu, \%28,6'sı özel kesim tarafından karşılanmaktadır. 1995 yilından 2006'ya kadar kamunun payında önemli bir değişim olmadığı görülmektedir. Sağlık hizmetleri içinde kamunun payının en yüksek olduğu ülkeler sırasıyla Lüksemburg, Çek Cumhuriyeti ve İngiltere'dir.

1995-2005 yılları arasında sağlık harcamalarının GSYİH içindeki payı tüm ülkelerde artma eğilimi göstermiştir. 1995-2005 döneminde sağlık harcamalarının yılık artış hızı OECD bölgesinde \%2,6 iken, Türkiye'de $\% 3,4^{\prime}$ tür. Bu dönemde en yüksek artış hızı Macaristan ve Polonya'da gerçekleşirken, en düşük artış hızı Japonya ve İsviçre'de ortaya çıkmıştır. 2000-2006 döneminde OECD bölgesinde yıllık artış hızı \%5,2 iken, Türkiye'de $\% 7,6$ olmuştur.

OECD ülkelerinde kişi başı sağlık harcama ortalaması 2824 dolardır. OECD bölgesinde kişi başına en yüksek sağlık harcaması yapılan ülkeler ise 6714 dolarla ABD, 4520 dolarla Norveç ve 4311 dolarla İsviçre'dir. En düşük harcama yapılan ülkeler ise Türkiye ile birlikte Meksika ve Polonya'dır. Türkiye'de kişi başına sağlık harcaması 1995 yılında 173 dolar iken, 2006 yılında 591 dolara yükselmiştir. Ancak, Türkiye, 1995-2006 yılları arasında sağlık harcamaları en hızlı 
Tablo 2

Seçilmiş OECD Ülkelerinde Sağlık Harcamaları ve Finansman Kaynakları

\begin{tabular}{|c|c|c|c|c|c|c|c|c|c|c|}
\hline \multirow[b]{2}{*}{ Ülkeler } & \multicolumn{2}{|c|}{$\begin{array}{c}\text { Sağlık } \\
\text { Harcamaları } \\
\text { /GSYİH }\end{array}$} & \multicolumn{2}{|c|}{$\begin{array}{c}\text { Sağlık } \\
\text { Harcamaları } \\
\text { İçinde } \\
\text { Kamunun } \\
\text { Payı (\%) }\end{array}$} & \multicolumn{2}{|c|}{$\begin{array}{c}\text { Yıllık Artış } \\
\text { H1zı }\end{array}$} & \multicolumn{2}{|c|}{$\begin{array}{l}\text { Kişi Başına Sağlık } \\
\text { Harcaması USD } \\
\text { (Satın alma Gücü } \\
\text { Paritesine Göre) }\end{array}$} & \multicolumn{2}{|c|}{$\begin{array}{l}1000 \text { Kişiye } \\
\text { Düşen } \\
\text { Doktor Sayısı }\end{array}$} \\
\hline & 2006 & 1995 & 2006 & 1995 & $\begin{array}{c}1995- \\
2005\end{array}$ & $\begin{array}{l}2000- \\
2006\end{array}$ & 2006 & 1995 & 2006 & 1995 \\
\hline Avustralya & 8,8 & 7,4 & 67,0 & 65,8 & 2,5 & 4,5 & 2999 & 1611 & 2,8 & 2,5 \\
\hline Avusturya & 10,1 & 9,7 & 76,2 & 72,6 & 2 & 2,0 & 3606 & 2259 & 3,6 & 2,7 \\
\hline Belçika & 10,4 & 8,2 & 69,1 & 71,1 & 1,7 & 5,0 & 3488 & 1854 & 4,0 & 3,5 \\
\hline Kanada & 10,0 & 9,0 & 70,4 & 71,4 & 2,3 & 4,7 & 3678 & 2057 & 2,1 & 2,1 \\
\hline Çek Cumhuriyeti & 6,8 & 7,0 & 87,9 & 90,9 & 2,7 & 4,7 & 1490 & 899 & 3,6 & 3,0 \\
\hline Danimarka & 9,5 & 8,1 & 79,9 & 79,7 & 1,7 & 4,1 & 3349 & 1871 & 3,6 & 3,1 \\
\hline Finlandiya & 8,2 & 7,7 & 76,0 & 74,1 & 3,4 & 5,6 & 2668 & 1440 & 2,7 & 2,4 \\
\hline Fransa & 11,1 & 9,9 & 79,7 & 78,6 & 1,6 & 4,2 & 3449 & 1997 & 3,4 & 3,2 \\
\hline Almanya & 10,6 & 10,1 & 76,9 & 81,6 & 1,2 & 1,4 & 3371 & 2275 & 3,5 & 3,1 \\
\hline Yunanistan & 9,1 & 8,6 & 61,6 & 52,0 & 3,4 & 7,2 & 2483 & 1264 & 5,0 & 3,9 \\
\hline Macaristan & 8,3 & 7,3 & 70,9 & 84,0 & 4,4 & 7,3 & 1504 & 660 & 3,0 & 3,0 \\
\hline İzlanda & 9,1 & 8,2 & 82,0 & 83,9 & 3,4 & 3,6 & 3340 & 1910 & 3,7 & 3,0 \\
\hline İrlanda & 7,5 & 6,7 & 78,3 & 71,9 & 6 & 8,8 & 3082 & 1204 & 2,9 & 2,1 \\
\hline İtalya & 9,0 & 7,3 & 77,2 & 70,8 & 1,1 & 2,8 & 2614 & 1538 & 3,7 & 3,9 \\
\hline Japonya & 8,2 & 6,9 & 82,7 & 83,0 & 0,9 & 2,5 & 2474 & 1551 & 2,1 & 1,8 \\
\hline Kore & 6,4 & 3,9 & 55,1 & 38,1 & 3,7 & 10,7 & 1480 & 502 & 1,7 & 1,1 \\
\hline Lüksemburg & 7,3 & 5,6 & 90,9 & 92,4 & 3,6 & 8,0 & 4303 & 1911 & 2,8 & 2,2 \\
\hline Meksika & 6,6 & 5,6 & 44,2 & 42,1 & 2,1 & 5,2 & 794 & 386 & 1,9 & 1,7 \\
\hline Hollanda & 9,3 & 8,3 & 81,7 & 71,0 & 2,1 & 4,1 & 3391 & 1799 & 3,8 & 2,9 \\
\hline Yeni Zelanda & 9,3 & 7,2 & 77,8 & 77,2 & 1,9 & 6,7 & 2448 & 1244 & 2,3 & 2,0 \\
\hline Norveç & 8,7 & 7,9 & 83,6 & 84,2 & 2,3 & 2,8 & 4520 & 1863 & 3,7 & 2,8 \\
\hline Polonya & 6,2 & 5,5 & 69,9 & 72,9 & 4,3 & 5,6 & 910 & 411 & 2,2 & 2,3 \\
\hline Portekiz & 10,2 & 7,8 & 70,6 & 62,6 & 1,7 & 3,3 & 2120 & 1036 & 3,4 & 2,9 \\
\hline Slovakya & 7,1 & 5,7 & 74,4 & 91,7 & 3,4 & 10,2 & 1130 & 564 & 3,1 & .. \\
\hline İspanya & 8,4 & 7,4 & 71,2 & 72,2 & 2,7 & 6,0 & 2458 & 1193 & 3,6 & 2,5 \\
\hline İsveç & 9,2 & 8,0 & 81,7 & 86,6 & 2,6 & 4,7 & 3202 & 1746 & 3,5 & 2,9 \\
\hline İsviçre & 11,3 & 9,7 & 60,3 & 53,8 & 1 & 3,2 & 4311 & 2598 & 3,8 & 3,2 \\
\hline Türkiye & 5,7 & 3,4 & 71,4 & 70,3 & 3,4 & 7,6 & 591 & 173 & 1,6 & 1,1 \\
\hline İngiltere & 8,4 & 6,9 & 87,3 & 83,9 & 2,4 & 5,1 & 2760 & 1350 & 2,5 & 1,8 \\
\hline ABD & 15,3 & 13,3 & 45,8 & 45,3 & 2,2 & 5,0 & 6714 & 3656 & 2,4 & 2,2 \\
\hline OECD Ortalaması & 8,9 & 7,6 & 73,0 & 72,9 & 2,6 & 5,2 & 2824 & 1494 & 3,1 & 2,6 \\
\hline
\end{tabular}

Kaynak: OECD Health Data 2008, OECD, Paris, June 2008.

StatLink: http://dx.doi.org/10.1787/467300445456 
artan ülkeler arasında yer almasına rağmen, OECD bölgesinde kişi başına sağlık harcaması en düşük olan ülke konumunu sürdürmektedir. 2000-2006 döneminde kişi başına sağlık harcaması en hızlı yükselen ülkeler Kore ve Slovakya iken, en az artan ülkeler Almanya ve Avusturya olmuştur. 1995-2006 dönemi dikkate alındığından kişi başına sağlık harcaması yüksek olan gelișmiș ülkelerde sağlık harcamalarındaki artış hızı, kişi başına sağlık harcaması düşüuk olan gelişmekte olan ülkelerden daha düşük kalmıştır. Bu durum, gelişmiş ülkelerde sağl1k hizmetlerinin 1995 öncesinde ulaştığ 1 yüksek seviyenin sonucudur.

OECD ülkelerinde kişi başına düşen doktor sayısında da büyük farklılıklar vardır. OECD bölgesinde ortalama olarak her 1000 kişiye 3,1 doktor düşerken, Yunanistan'da 5, Belçika'da 4, Türkiye'de ise sadece 1,6 doktor düşmektedir. Türkiye kişi başına doktor sayısı bakımından da OECD ülkeleri arasinda en son sirada yer almaktadır.

Dünya Sağllk Örgütü verilerine göre; Türkiye'de sağlık harcamalarının finansmanında kamunun pay1 1975 'te \%50 iken, bu oran 1978 'de \%20'ye kadar düşmüştür. 1985'e kadar geçen sürede kamunun payı \%50'nin altında ve oldukça dalgalı bir seyir izlemiştir. 1988' den sonra nisbeten istikrarlı bir yükseliş trendi ile 1990'da \%61'e, 1995'te \%70,3'e yükselmiş, 1999'da tekrar \%60'lar seviyesine düşmüş, 2001 yılından sonra \%70'ler seviyesinde stabilize olmuştur. Satın alma gücü paritesine göre 1975 yılında 45 dolar olan kişi başına sağlık harcaması 1980'de 70, 1985'te 86,1990 'da 156,2000 'de 432, 2006'da 591 dolara yükselmiştir.

Tablo 4'te OECD ülkelerinin sağlık durumu ile ilgili temel göstergeler sunulmuştur. Ekonomik ve sosyal koşullardaki genel gelişmelerin yanı sıra, çocuk aşılarından yararlanma dahil, doğum sonrası sağlık hizmetlerindeki düzelmeler yıllar içinde OECD ülkelerinde bebek ölüm oranlarında dikkate değer bir düşüş sağlamıştır. Türkiye'de 1995 yılında her 1000 bebekten 43 tanesi hayatını kaybederken, bu sayı 2006 yılında yaklaşık 22,6'ya düşmüştür. Ne var ki Türkiye hala bebek ölüm oranının en yüksek olduğu ülke konumundadır. Bebek ölüm oranının en düşük olduğu ülkeler, binde 2,6 ile Japonya ve İzlanda'dır.

Türkiye'de 1995 yılında 67,9 yıl olan doğuşta yaşam beklentisi 2006 yılında 71,6 yıla yükselmiştir. Doğuşta yaşam beklentisi kadınlarda 74 iken, erkeklerde 69,1'dir. Bu iyileşmeye rağmen, Türkiye yaşam beklentisi açısından en son sırada yer almaktadır. OECD ülkeleri arasında Japonya 82,4 yil ile yaşam beklentisi açısından ilk sırada yer almaktadır. Japonya'da doğuşta yaşam beklentisi kadinlarda 85,8 iken, erkeklerde 79 'dur. OECD ülkelerinin tamaminda kadınların yaşam beklentisi erkeklerden daha yüksektir.

Türkiye, doğurganlık oranında, OECD ülkeleri arasında kadın başına 2,18 çocukla birinci sirada yer almaktadır. Türkiye'yi 2,17 ile Meksika takip ederken, en son sirada 1,13 çocukla Kore yer almaktadır. Kadın başına çocuk sayısı OECD bölgesinde 1,65'tir.

\section{5. İnsani Gelişmişlik Açısından Türkiye'nin Durumu}

Eğitim ve sağlık göstergeleri, gelir kriteriyle birlikte Birleşmiş Milletler Kalkınma Programı (UNDP) tarafından yayınlanan İnsani Gelişme Raporlarında, bir ülkenin ekonomik gelişmişliğinin insani boyutunu gösteren temel göstergeler olarak kabul edilmektedir. Genel olarak, eğitim ve sağlık göstergeleri ile gelir düzeyi arasında aynı yönlü ilişki vardır; gelir düzeyi yüksek ülkeler genellikle daha iyi eğitim ve sağlık standartlarına sahiptirler.

İnsani gelişme raporlarında bir ülkenin gelişmişlik düzeyi üç endeks dikkate alınarak belirlenmektedir. Bunlar; satın alma gücü paritesine göre hesaplanan kişi başına gayri safi yurtiçi hâsılayı ifade eden gelir endeksi (GSYİH endeksi), yetişkinler arası okuma düzeyi ve okullaşma oranından oluşan eğitim endeksi ve yaşam beklentisi endeksleridir.

İnsani gelişme endeksinin değeri 0 ile 1 arasında değişmekte olup; endeks değerinin 1'e 
Tablo 4

\section{Seçilmiş OECD Ülkelerinde Sağlik Durumu}

\begin{tabular}{|c|c|c|c|c|c|c|c|c|c|}
\hline \multirow[b]{3}{*}{ Ülkeler } & \multicolumn{6}{|c|}{ Doğuşta Beklenen Yaşam Süresi } & \multirow{3}{*}{$\begin{array}{c}\text { Doğurganlık } \\
\text { Oranı } \\
\text { (Kadın } \\
\text { Başına } \\
\text { Doğum } \\
\text { Sayısı) } \\
2006\end{array}$} & \multirow{2}{*}{\multicolumn{2}{|c|}{$\begin{array}{c}\text { Bebek Ölüm Hızı } \\
\text { (Canlı Doğan Her } \\
1000 \text { Bebek Başına } \\
\text { Ölüm Oranı) }\end{array}$}} \\
\hline & \multicolumn{3}{|c|}{2006} & \multicolumn{3}{|c|}{1995} & & & \\
\hline & Kadın & Erkek & Toplam & Kadın & Erkek & Toplam & & 2006 & 1995 \\
\hline Avustralya & 83,5 & 78,7 & 81,1 & 80,8 & 75,0 & 77,9 & 1,81 & 4,7 & 5,7 \\
\hline Avusturya & 82,7 & 77,1 & 79,9 & 79,9 & 73,3 & 76,6 & 1,41 & 3,6 & 5,4 \\
\hline Belçika & 82,3 & 76,6 & 79,5 & 80,4 & 73,5 & 77,0 & 1,80 & 3,7 & 5,9 \\
\hline Kanada & 82,7 & 78,0 & 80,4 & 81,1 & 75,1 & 78,1 & 1,54 & 5,4 & 6,1 \\
\hline Çek Cumhuriyeti & 79,9 & 73,5 & 76,7 & 76,8 & 69,7 & 73,3 & 1,33 & 3,3 & 7,7 \\
\hline Danimarka & 80,7 & 76,1 & 78,4 & 77,9 & 72,7 & 75,3 & 1,85 & 3,8 & 5,1 \\
\hline Finlandiya & 83,1 & 75,9 & 79,5 & 80,4 & 72,8 & 76,6 & 1,84 & 2,8 & 3,9 \\
\hline Fransa & 84,4 & 77,3 & 80,9 & 81,8 & 73,9 & 77,9 & 1,98 & 3,8 & 4,9 \\
\hline Almanya & 82,4 & 77,2 & 79,8 & 79,9 & 73,3 & 76,6 & 1,33 & 3,8 & 5,3 \\
\hline Yunanistan & 82,0 & 77,1 & 79,6 & 80,3 & 75,0 & 77,7 & 1,41 & 3,7 & 8,1 \\
\hline Macaristan & 77,4 & 69,0 & 73,2 & 74,5 & 65,3 & 69,9 & 1,35 & 5,7 & 10,7 \\
\hline İzlanda & 83,0 & 79,4 & 81,2 & 80,0 & 75,9 & 78,0 & 2,07 & 1,4 & 6,0 \\
\hline İrlanda & 82,1 & 77,3 & 79,7 & 78,3 & 72,8 & 75,6 & 1,90 & 3,7 & 6,4 \\
\hline İtalya & 83,8 & 77,9 & 80,9 & 81,6 & 75,1 & 78,4 & 1,35 & 3,9 & 6,2 \\
\hline Japonya & 85,8 & 79,0 & 82,4 & 82,9 & 76,4 & 79,6 & 1,32 & 2,6 & 4,3 \\
\hline Kore & 82,4 & 75,7 & 79,1 & 77,4 & 69,6 & 73,5 & 1,13 &.. & 7,7 \\
\hline Lüksemburg & 81,9 & 76,8 & 79,4 & 80,6 & 73,0 & 76,8 & 1,64 & 2,5 & 5,5 \\
\hline Meksika & 78,1 & 73,2 & 75,7 & 75,3 & 70,0 & 72,7 & 2,17 & 18,1 & 27,6 \\
\hline Hollanda & 81,9 & 77,6 & 79,8 & 80,4 & 74,6 & 77,5 & 1,72 & 4,4 & 5,5 \\
\hline Yeni Zelanda & 81,9 & 77,9 & 79,9 & 79,7 & 74,4 & 77,1 & 2,01 & 5,2 & 6,7 \\
\hline Norveç & 82,9 & 78,2 & 80,6 & 80,9 & 74,8 & 77,9 & 1,90 & 3,2 & 4,0 \\
\hline Polonya & 79,6 & 70,9 & 75,3 & 76,4 & 67,6 & 72,0 & 1,27 & 6,0 & 13,6 \\
\hline Portekiz & 82,3 & 75,5 & 78,9 & 79,0 & 71,7 & 75,4 & 1,36 & 3,3 & 7,5 \\
\hline Slovakya & 78,2 & 70,4 & 74,3 & 76,3 & 68,4 & 72,4 & 1,24 & 6,6 & 11,0 \\
\hline İspanya & 84,4 & 77,7 & 81,1 & 81,8 & 74,4 & 78,1 & 1,38 & 3,8 & 5,5 \\
\hline İsveç & 82,9 & 78,7 & 80,8 & 81,4 & 76,2 & 78,8 & 1,85 & 2,8 & 4,1 \\
\hline İsviçre & 84,2 & 79,2 & 81,7 & 81,9 & 75,4 & 78,7 & 1,44 & 4,4 & 5,0 \\
\hline Türkiye & 74,0 & 69,1 & 71,6 & 70,2 & 65,6 & 67,9 & 2,18 & 22,6 & 43,0 \\
\hline Büyük Britanya & 81,1 & 77,1 & 79,1 & 79,3 & 74,0 & 76,7 & 1,84 & 5,0 & 6,2 \\
\hline $\mathrm{ABD}$ & 80,4 & 75,2 & 77,8 & 78,9 & 72,5 & 75,7 & 2,10 & 6,9 & 7,6 \\
\hline OECD Ortalaması & 81,7 & 76,1 & 78,9 & 79,2 & 72,7 & 76,0 & 1,65 & 5,2 & 8,4 \\
\hline
\end{tabular}

Kaynak: OECD in Figures 2008

StatLink: http:/ /dx.doi.org/10.1787/467310041335;

Sources: OECD Health Data 2008, OECD, Paris, June 2008. 
yaklaşması, ülkede insani gelişme performansının iyileștiği anlamına gelmektedir. İnsani gelişme endeksinde ülkeler; yüksek, orta ve düşük düzeyde insani gelişme seviyesine sahip ülkeler olarak üç gruba ayrılmaktadır. 0 ile 0,499 arasındaki endeks değerlerine sahip ülkeler "düşük insani gelişmiş ülkeler", 0,500 ile 0,799 arasındaki endeks değerlerine sahip ülkeler "orta insani gelişmiş ülkeler" ve 0,800 'den daha yüksek endeks değerine sahip ülkeler "yüksek insani gelişmiş ülkeler" olarak sinıflandırılmaktadırlar. Türkiye, 0,775 endeks değeri ile insani gelişmişlik açısından orta insani gelişmiş ülkeler kategorisinde yer almaktadır.

Tablo 5'te, UNDP 2007-2008 İnsani Gelişme Raporundan derlenen, seçilmiş ülkelere ait en son insani gelişme verileri yer almaktadır. İnsani Gelişme Raporuna göre; Türkiye 177 ülke arasında 84. sirada yer almaktadır. Türkiye, 0,775 insani gelişme endeks değeri ile orta düzeyde insani gelişme performansı gösteren ülkeler grubunun üyesidir. Türkiye, bu endeks değeri ile OECD bölgesinde en son sirada yer almaktadır. Türkiye, bütün gelişmekte olan ülkelerin ortalaması olan 0,691 ve içinde yer aldığı, orta insani gelişmişliğe sahip ülkelerin ortalaması olan 0,698 değerinden daha yüksek endeks değerine sahiptir. Ayrıca, Türkiye'nin endeks değeri Dünya ortalaması olan 0,743'ten daha yüksektir.

İnsani Gelişme Endeksinde ilk sırada İzlanda yer almaktadır. Kişi başına GSYİH'sı İzlanda'dan daha yüksek ülkeler bulunmasina karşılık, eğitim ve sağlık endeksleri bakımından diğer ülkelerden daha iyi konumda olması, İzlanda'yı ilk sıraya taş1maktadır. İzlanda'yı Norveç ve Avustralya takip etmektedir. Listenin en sonunda sirasiyla Sierra Leone, Burkina Faso ve Gine yer almaktadir.

Yaşam beklentisi endeksine göre; ilk üç s1rada Japonya, Hon Kong ve İzlanda yer almaktadır. Yaşam beklentisi endeksi açısından en son sırada yer alan ülkeler; Zimbabwe ve Zambiya'dır. Eğitim endeksine göre ilk üç sirada yer alan ülkeler; Avustralya, İrlanda ve Finlandiya iken, listenin en altında Mali, Nijer ve Burkina Faso yer almaktadır. Gelir endeksine göre 1 endeks değeri ile listenin ilk üç sırasını; ABD, Lüksemburg ve Norveç paylaşmaktadır. Listenin en altında ise, Demokratik Kongo Cumhuriyeti, Burundi ve Malawi bulunmaktadır.

Gelişmekte olan ülkelerde ekonomik büyüme sürecinde ortaya çıkan önemli bir sorun, büyümenin nimetlerinin toplumsal sınıflar arasında dengesiz dağılımıdır. Büyüme sürecinde gelir dağılımı daha adaletsiz hale gelirken, yoksulluk istatistiklerinde beklenen iyileşme gerçekleşmemektedir. Bu durum, insani gelişme indeksinde, gelir endeksine göre daha üst sıralarda bulunan ülkelerin sağlık ve eğitim endeksleri dikkate alındığında daha alt sıralara düşmesine yol açmaktadır. Türkiye için de benzer bir durum söz konusudur; gelir endeksine göre daha üst sıralarda bulunmasına rağmen, eğitim ve sağllk endeksleri devreye girdiğinde Türkiye kendisinden gelir endeksi bak1minda daha alt siralarda bulunan ülkelerin gerisinde kalmaktadır. Türkiye'nin gelir endeks değeri, yüksek insani gelişmiş ülkeler grubunda yer alan bir kısım sahip ülkelerden daha iyidir. Örneğin yüksek insani gelişmiş ülkeler grubunda yer alan; Panama, Arnavutluk, Bosna-Hersek ve Makedonya gelir endeksinde Türkiye'nin altında yer almaktadır. Türkiye; orta düzeyde insani gelişme performansı gösteren ülkeler arasında 14. sırada yer almaktadır. Halbuki Türkiye'nin önündeki 13 ülkeden sadece Tayland gelir endeksi bakımından daha iyi konumdadir (Human Development Report 2007/2008: 229-230). Bu ülkelerin insani gelişmenin eğitim ve sağlık göstergeleri devreye girdiğinde daha üst siralarda yer alması, bu ülkelerde gelişmenin nimetlerinin nisbeten daha adil dağıldığı, ekonomik göstergeler ile sosyal göstergeler arasındaki bağlantının Türkiye'den daha güçlü olduğunu göstermektedir. Bu çarpık durumunun düzeltilmesi için Türkiye'de insani gelişmenin eğitim ve sağlık boyutuna daha fazla ağırlık verilmesi gerekmektedir.

İnsani Gelişme Raporu 2007-2008'e göre Türkiye; 2005 yılında kişi başına 8407 dolar 
Tablo 5

Seçilmiş Ülkelerin İnsani Gelişmişlik Endeksi Verileri 2005

\begin{tabular}{|c|c|c|c|c|c|c|c|c|}
\hline Ülkeler & 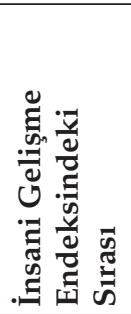 & 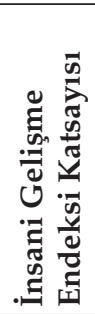 & 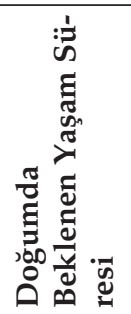 & 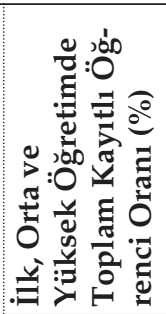 & 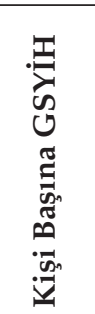 & 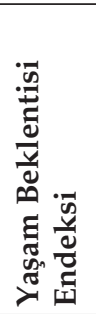 & 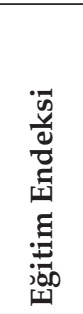 & 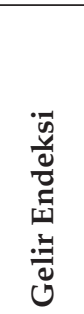 \\
\hline İzlanda & 1 & 0,968 & 81,5 & 95,4 & 36510 & 0,941 & 0,978 & 0,985 \\
\hline Norveç & 2 & 0,968 & 79,8 & 99,2 & 41420 & 0,913 & 0,991 & 1,00 \\
\hline Avustralya & 3 & 0,962 & 80,9 & 113,0 & 31794 & 0,931 & 0,993 & 0,962 \\
\hline Kanada & 4 & 0,961 & 80,3 & 99,2 & 33375 & 0,921 & 0,991 & 0,97 \\
\hline İsviçre & 7 & 0,955 & 81,3 & 85,7 & 35633 & 0,938 & 0,946 & 0,981 \\
\hline Japonya & 8 & 0,953 & 82,3 & 85,9 & 31267 & 0,954 & 0,946 & 0,959 \\
\hline Hollanda & 9 & 0,953 & 79,2 & 98,4 & 32684 & 0,904 & 0,988 & 0,966 \\
\hline Fransa & 10 & 0,952 & 80,2 & 96,5 & 30386 & 0,919 & 0,982 & 0,954 \\
\hline $\mathrm{ABD}$ & 12 & 0,951 & 77,9 & 93,3 & 41890 & 0,881 & 0,971 & 1,00 \\
\hline İspanya & 13 & 0,949 & 80,5 & 98,0 & 27169 & 0,925 & 0,987 & 0,935 \\
\hline Danimarka & 14 & 0,949 & 77,9 & 102,7 & 33973 & 0,881 & 0,993 & 0,973 \\
\hline Avusturya & 15 & 0,948 & 79,4 & 91,9 & 33700 & 0,907 & 0,966 & 0,971 \\
\hline İngiltere & 16 & 0,946 & 79,0 & 93,0 & 33238 & 0,9 & 0,97 & 0,969 \\
\hline Belçika & 17 & 0,946 & 78,8 & 95,1 & 32119 & 0,897 & 0,977 & 0,963 \\
\hline Yeni Zelanda & 19 & 0,943 & 79,8 & 108,4 & 24996 & 0,913 & 0,993 & 0,922 \\
\hline İtalya & 20 & 0,941 & 80,3 & 90,6 & 28529 & 0,922 & 0,958 & 0,944 \\
\hline Almanya & 22 & 0,935 & 79,1 & 88,0 & 29461 & 0,902 & 0,953 & 0,949 \\
\hline Yunanistan & 24 & 0,926 & 78,9 & 99,0 & 23381 & 0,898 & 0,97 & 0,91 \\
\hline Kore & 26 & 0,903 & 79,0 & 77,6 & 22699 & 0,9 & 0,904 & 0,905 \\
\hline Portekiz & 29 & 0,897 & 77,7 & 89,8 & 2041 & 0,879 & 0,925 & 0,888 \\
\hline Çek Cumhuriyeti & 32 & 0,891 & 75,9 & 82,9 & 20538 & 0,849 & 0,936 & 0,889 \\
\hline Macaristan & 36 & 0,874 & 72,9 & 89,3 & 17887 & 0,799 & 0,958 & 0,866 \\
\hline Polonya & 37 & 0,870 & 75,2 & 87,2 & 13847 & 0,836 & 0,951 & 0,823 \\
\hline Meksika & 52 & 0,829 & 75,6 & 75,6 & 10751 & 0,843 & 0,863 & 0,781 \\
\hline Bulgaristan & 53 & 0,824 & 72,7 & 81,5 & 9032 & 0,795 & 0,926 & 0,752 \\
\hline Romanya & 60 & 0,813 & 71,9 & 76,8 & 9060 & 0,782 & 0,905 & 0,752 \\
\hline Rusya & 67 & 0,802 & 65,0 & 88,9 & 10845 & 0,667 & 0,956 & 0,782 \\
\hline Türkiye & 84 & 0,775 & 71,4 & 68,7 & 8407 & 0,773 & 0,812 & 0,740 \\
\hline Gine & 175 & 0,374 & 45,8 & 36,7 & 827 & 0,347 & 0,421 & 0,353 \\
\hline Burkina Faso & 176 & 0,370 & 51,4 & 29,3 & 1213 & 0,440 & 0,255 & 0,417 \\
\hline Sierra Leone & 177 & 0,336 & 41,8 & 44,6 & 806 & 0,280 & 0,381 & 0,348 \\
\hline $\begin{array}{l}\text { Gelişmekte Olan } \\
\text { Ülkeler }\end{array}$ & - & 0,691 & 66,1 & 64,1 & 5282 & 0,685 & 0,725 & 0,662 \\
\hline OECD & - & 0,916 & 78,3 & 88,6 & 29197 & 0,888 & 0,912 & 0,947 \\
\hline $\begin{array}{l}\text { Yüksek İnsani } \\
\text { Gelişmiş Ülkeler }\end{array}$ & - & 0,897 & 76,2 & 88,4 & 23986 & 0,854 & 0,922 & 0,915 \\
\hline $\begin{array}{l}\text { Orta İnsani } \\
\text { Gelişmiş Ülkeler }\end{array}$ & - & 0,698 & 67,5 & 65,3 & 4876 & 0,709 & 0,738 & 0,649 \\
\hline $\begin{array}{l}\text { Düşük İnsani } \\
\text { Gelişmiş Ülkeler }\end{array}$ & - & 0,436 & 48,5 & 45,8 & 1112 & 0,391 & 0,516 & 0,402 \\
\hline Dünya & - & 0,743 & 68,1 & 67,8 & 9543 & 0,718 & 0,750 & 0,761 \\
\hline
\end{tabular}

Kaynak: Human Development Report 2007/2008, UNDP, ss.229-232 


\section{Tablo 6}

Türkiye'nin İnsani Gelişmişlik Endeksi Değerleri (1980-2005)

\begin{tabular}{|c|c|c|c|c|c|}
\hline Yillar & $\begin{array}{c}\text { Kişi Başına } \\
\text { GSYİH (SGP/\$) }\end{array}$ & $\begin{array}{c}\text { İnsani Gelişme } \\
\text { Endeksi } \\
\text { Katsayısı }\end{array}$ & $\begin{array}{c}\text { Yaşam Beklentisi } \\
\text { Endeksi }\end{array}$ & Eğitim Endeksi & Gelir Endeksi \\
\hline 1980 & 2252 & 0,588 & 0,61 & 0,62 & 0,52 \\
\hline 1981 & 2542 & 0,599 & 0,62 & 0,62 & 0,54 \\
\hline 1982 & 2724 & 0,609 & 0,62 & 0,63 & 0,55 \\
\hline 1983 & 2914 & 0,620 & 0,63 & 0,64 & 0,56 \\
\hline 1984 & 3174 & 0,631 & 0,64 & 0,66 & 0,57 \\
\hline 1985 & 3340 & 0,639 & 0,65 & 0,67 & 0,58 \\
\hline 1986 & 3582 & 0,646 & 0,65 & 0,68 & 0,59 \\
\hline 1987 & 3965 & 0,660 & 0,66 & 0,68 & 0,61 \\
\hline 1988 & 4114 & 0,667 & 0,66 & 0,69 & 0,62 \\
\hline 1989 & 4213 & 0,672 & 0,68 & 0,70 & 0,62 \\
\hline 1990 & 4691 & 0,682 & 0,68 & 0,70 & 0,64 \\
\hline 1991 & 4822 & 0,689 & 0,69 & 0,71 & 0,64 \\
\hline 1992 & 5105 & 0,696 & 0,69 & 0,72 & 0,65 \\
\hline 1993 & 5562 & 0,705 & 0,70 & 0,73 & 0,67 \\
\hline 1994 & 5280 & 0,708 & 0,71 & 0,74 & 0,66 \\
\hline 1995 & 5620 & 0,713 & 0,71 & 0,75 & 0,67 \\
\hline 1996 & 5999 & 0,721 & 0,72 & 0,75 & 0,68 \\
\hline 1997 & 6350 & 0,728 & 0,73 & 0,75 & 0,69 \\
\hline 1998 & 6422 & 0,733 & 0,73 & 0,75 & 0,69 \\
\hline 1999 & 6380 & 0,735 & 0,74 & 0,77 & 0,69 \\
\hline 2000 & 6974 & 0,753 & 0,75 & 0,77 & 0,71 \\
\hline 2001 & 5890 & 0,734 & 0,75 & 0,77 & 0,68 \\
\hline 2002 & 6390 & 0,751 & 0,76 & 0,80 & 0,69 \\
\hline 2003 & 6772 & 0,750 & 0,73 & 0,82 & 0,70 \\
\hline 2004 & 7753 & 0,757 & 0,73 & 0,81 & 0,69 \\
\hline 2005 & 8407 & 0,775 & 0,773 & 0,812 & 0,740 \\
\hline
\end{tabular}

Kaynak: UNDP Human Development Report, 2007/2008, s.230;

UNDP Human Development Report, 2004, s.140

UNDP Human Development Report, 2006, s.284, 289.; 294.

http:/ /hdr.undp.org/

UNDP Human Development Report, 2003;

UNDP Human Development Report, 2001; s.142, 146

Muhsin Kar and Sami Taban, 2005, "Human Capital Accumulation Policy in Turkey in the Eve of the EU Accession", Presented at the 2005 Conference on Medium Term Economic Assessment "Labour Market Transformation Towards KnowledgeBased Economy", Agency for Economic Analysis and Forecasting, 29-30 September, Sofya, Bulgaristan. 
gelir ile 66 . sirada, $\% 87,4$ yetişkin okuryazar oranı 69. sırada, 71,4 yıl doğumda yaşam beklentisi ile 85 . sirada, $\% 68,7$ ilk, orta ve yüksek öğretim brüt okullaşma oranı 108. s1rada yer almaktadır. Eğitim ve yaşam beklentisi endekslerinin düşüklüğü, gelir endeksine göre 67. sırada yer alan Türkiye'yi 18 sıra geriye iterek insani gelişme endeksinde 84. sıraya düşürmektedir. İnsani gelişme endeks değeri 0,775 olan Türkiye'nin eğitim endeks değeri 0,812 , yaşam beklentisi endeks değeri 0,773 ve yurt içi gayri safi yurt hâsıla (gelir) endeks değeri 0,740'tır. Listenin zirvesinde 0,968 insani gelişme endeks değeri ile İzlanda, 82.3 yıl doğumda yaşam beklentisi ile Japonya, \%100 yetişkin okuryazarlığı ile Ermenistan, satın alma gücü paritesine göre 60228 dolar kişi başına gelir ile Lüksemburg ve \%113 ilk, orta ve yüksek öğretim brüt okullaşma oranı Avustralya yer almaktadır.

Listenin en alt sirasinda ise 0,336 insani gelişme endeks değeri ile Sierra Leone, 40,5 yıl doğumda yaşam beklentisi ile Zambiya, $\% 23,6$ yetişkin okuryazarlığ 1 ile Burkina Faso, satın alma gücü paritesine göre 667 dolar kişi başına gelir ile Malawi ve $\% 22,7$ ilk, orta ve yüksek öğretim brüt okullaşma oranı Nijer yer almaktadır.

Tablo 6'da Türkiye'nin 1980-2005 dönemine ait insani gelişme endeksi ile insani gelişme endeksine temel oluşturan eğitim, yaşam beklentisi ve gelir alt endekslerine ait değerler yer almaktadır. 177 ülke arasında 0,775 insani gelişme endeks değeri ile insani gelişmişlik siralamasında 84. sirada yer alan Türkiye, yaşam beklentisi endeksine göre $(0,773$ endeks değeriyle) 85. sırada, eğitim endeksine göre $(0,812$ endeks değeriyle) 104 . s1rada, gelir endeksine göre $(0,74$ endeks değeriyle) 67. sırada yer almaktadır. Türkiye'yi insani gelişmişlik sıralamasında aşağ $1-$ lara iten önemli faktör, eğitim endeksinin düşüklüğüdür.

Muhsin Kar and Sami Taban, 2005, "Human Capital Accumulation Policy in Turkey in the Eve of the EU Accession", Presented at the 2005 Conference on Medium Term Economic Assessment "Labour Market Trans- formation Towards KnowledgeBased Economy", Agency for Economic Analysis and Forecasting, 29-30 September, Sofya, Bulgaristan.

Tablo 6 incelendiğinde yaşam beklentisi endeksinin istikrarlı biçimde yükseldiği görülmektedir. 1980'de 0,61 olan endeks değeri, 1990 'da $0,68,1995$ 'te $0,71,2000$ 'de 0,75 ve 2005 'te $0,77^{\prime}$ ye yükselmiştir. Eğitim endeksi ise 1980 yılında 0,62 iken 2003 yılında 0,82'ye yükselmiştir. Ne var ki 2004 'te 0,81'e düşmüştür.

Gelir endeksi ekonomik kriz yılları dışında sürekli yükselmiştir. 1980'de 0,52 olan endeks değeri, 1988'de 0,62 olmuştur. 1989 ve 1991 yıllarında bir önceki yıla göre endeks değişmemiştir. 1994'te endeksin değeri düşmüş, 1998 ve 1999 'da sabit kalmış, 2001 y1lında 1996 seviyesine gerilemiştir. 2003'te 0,7'ye yükselen endeks 2004 'te 0,69 'a gerilemiştir.

\section{SONUÇ}

Eğitim ve sağlık, beşeri sermaye donanımına katkı yapan en önemli faktörlerdir. Tüm vatandaşların maddi gücüne bakılmaksızın asgari düzeyde sağlık güvencesine sahip olması, en azından temel seviyede eğitim hakkına sahip olması, çağdaş sosyal devlet anlayışının gereklerindendir. Bir ülkede, eğitim ve sağlığa ayrılacak kaynak miktarı, ekonomik gelişmişlik düzeyi ile yakından ilgilidir. Sosyal devlet anlayışı çerçevesinde ağırlıklı olarak devlet tarafindan sunulan bu hizmetlerin belirli bir maliyeti vardır ve bu maliyet devlet tarafından karşılanmaktadır. Türkiye ekonomisi büyüyüp, güçlendikçe eğitim ve sağlık alanına daha fazla kaynak aktarılması mümkün olacaktır.

Eğitim ve sağlık alanına yapılacak yatırımlarla beşeri sermaye donanımının artırılması, Türkiye'nin sahip olduğu, ağırlıklı olarak gençlerden oluşan insan gücü potansiyelinin etkin kullanıminda önemli rol oynayacaktır. Beşeri sermaye donanımındaki gelişmeler, bireysel açıdan önemli getiriler sağlayacağ gibi; ekonomik büyüme hızının yükseltilmesine de katkı sağlayacaktır. 
Türkiye'de son yıllarda eğitim ve sağlık alanında önemli gelişmeler kaydedilmiștir. Ancak, her iki alan açısından, gelişmiş ülkelerle karşılaştırıldığında henüz arzulanan seviyenin yakalanamadığı görülmektedir. OECD ülkelerinde eğitime ortalama olarak GSYİH'dan \%5,8 pay ayrılmakta iken, Türkiye'de \%4,1 pay ayrılmaktadır. Türkiye, 1995-2004 döneminde, OECD bölgesinde sabit fiyatlarla eğitim harcamalarında en büyük artışın gerçekleştiği ülke olmasına rağmen, tüm eğitim kademelerinde OECD ülkeleri arasında öğrenci bașına en az harcama yapan ve eğitime GSYİH'dan en düşük pay ayıran ülkedir.

Türkiye'de son yıllarda sağlık harcamalarında da gerek GSYİH'ya oran olarak, gerekse kişi başına harcama açısından önemli artışlar sağlanmıştır. 1995 yılında sağlığa GSYİH'dan \%3,4 pay ayrilmakta iken, bu oran 2006 'da \%5,7'ye yükselmiş, 1995'te 173 dolar olan kişi başına sağlık harcaması, 2006 'da 591 dolar olmuştur. Ancak, Türkiye her iki sağlık harcaması kriteri açısından OECD ülkeleri arasında en son sıradaki yerinden kurtulamamıștır. Türkiye, 1000 kişiye düşen doktor sayısı, yaşam beklentisi ve bebek ölüm hızı göstergeleri açısından da OECD bölgesinde en kötü durumda olan ülkedir.

Gelişmekte olan ülkelerde ekonomik büyüme sürecinde ortaya çıkan önemli bir sorun; büyümenin nimetlerinin toplumsal sinıflar arasında adaletsiz dağılımıdır. Bu ülkelerde gelir seviyesi yükseldikçe; beklenilenin aksine, gelir dağılımı daha adaletsiz hale gelirken, yoksulluk göstergeleri daha da bozulmaktadır. Bu nedenle, UNDP 1990'larda bir ülkenin gelişmişliğinin insani boyutu değerlendirilirken kişi başına GSYİH (gelir) kriterinin tek başına yeterli olmad1ğını kabul ederek, eğitim ve sağlık göstergelerini de içeren insani gelişme endeksini yayınlamaya başlamıştır. Bir kısım ülkeler, insani gelişme endeksinde gelir kriteri aç1sindan daha iyi konumda bulunmalarına rağmen, sağlık ve eğitim kriterlerinde yeterli gelişmeyi sağlayamadıkları için alt sıralara düşmektedirler. Türkiye için de benzer bir olumsuz durum söz konusudur. 177 ülke arasında 0,775 insani gelişme endeks değeri ile 84. sirada yer alan Türkiye, 0,773 yaşam beklentisi endeks değeriyle 85 . sirada, 0,812 eğitim endeks değeriyle 104. sirada, 0,74 gelir endeks değeriyle 67. sırada yer almaktadir.

Türkiye'yi insani gelişmişlik sıralamasında aşağılara iten önemli etken eğitim ve sağlık endeksinin yetersiz olmasidir. Bu nedenle, Türkiye'de eğitim ve sağlık yatırımlarına ağırlık verilmesi, ekonomik göstergeler ile sosyal göstergeler arasındaki bağlantının daha güçlü hale getirilmesine katkı sağlayarak, insani gelişmişlik açısından Türkiye'nin daha üst sıralara yükselmesini sağlayacaktır. 


\section{KAYNAKÇA}

Aguayo-Rico A. ve Diğ. (2005), “Empirical Evidence of the Impact of Health on Economic Growth", Issues in Political Economy, Vol. 14, August: 1-17.

Altay, A. (2005), “Türkiye'de Beşeri Sermayenin Karşılaştırmalı Analizi", TÜGİAD Bilimsel Eser Yarışması Birincilik Ödülü, http:/ / www.elegans.com.tr

Altay, A. ve Pazarlıoğlu, M.V. (2007), "Uluslararası Rekabet Gücünde Beşeri Sermaye: Ekonometrik Yaklaşım", Selçuk Üniversitesi Karaman İ̈BF Dergisi, Y1l 9, Say1 12, Haziran: 96-108.

Arısoy, E. ve Demir, R. (2001), “Eğitim, Haberleşme ve Ticari Serbestliğin Ekonomik Büyümeye Katkısı", http://www.dtm.gov.tr/

Becker, G.S. (1962), “Investment in Human Capital: A Theoretical Analysis", Journal of Political Economy, Vol. 70, No. 5: 9-49.

Bloom D.E. ve Canning D. (1999), "The Health and The Wealth of Nations", http:/ / www.riverpath.com

Bloom D.E., Canning D. ve Jamison D. T. (2004), "Health, Wealth, and Welfare", Finance \& Development, March: 10-15.

Bloom D.E., Canning D. ve Sevilla J. (2002), Health, Worker Productivity, and Economic Growth,

Bloom D.E. ve Canning D. (2000), "The Health and Wealth of Nations", Science, 287: 1207-1208.

Bloom D.E., Canning D. ve Graham B. (2002), "Longevity and Life Cycle Savings", NBER Working Paper Series, No. 8808 .
Bloom, D.E., Canning ve D. Sevilla, J. (2001), "The Effect of Health on Economic Growth: Theory and Evidence", NBER Working Paper Series, 8587.

Borghans, L. ve Heijke, H. (2005), “The Production and Use of Human Capital: Introduction", Education Economics Vol. 13, No. 2: 133-142.

Brunello, G. (2001), Unemployment, Education and Earnings Growth, IZA DP No. 311, http:/ /www.iza.org/

Çakmak, E. ve Gümüş, S. (2004), Türkiye'de Beşeri Sermaye ve Ekonomik Büyüme: Ekonometrik Bir Analiz (1960 - 2002), Ankara Üniversitesi SBF Dergisi, 601:59-72.

Çalışkan, M.İ. (2006), “AB Sürecinde Türkiye ile AB Ülkeleri Eğitim İstatistiklerinin Karşılaştırması", Türk Eğitim Bilimleri Dergisi, Güz, 4 (4): 375-394.

Dahlin, B.G. (2002), "The Impact of Education on Economic Growth Theory, Findings, and Policy Implications", http://www.duke.edu

Demir, S. (2006), “Birleşmiş Milletler Kalkınma Programı İnsani Gelişme Endeksi ve Türkiye Açısından Değerlendirme", DPT Sosyal Sektörler ve Koordinasyon Genel Müdürlüğü, Ankara.

Denison, E. (1962), The Sources of Economic Growth in the United States, Committee for Economic Development, New York.

Doğan, S. ve Şanlı, B. (2003), "İktisadi Kalkınmada Beşeri Sermaye", Süleymen Demirel Üniversitesi İIBF Dergisi, C.8, S.1: 173-196. 
Dura C., Atik, H. ve Türker O. (2004), “Beşeri Sermaye Açısından Türkiye'nin Avrupa Birliği Karşısındaki Kalkınma Seviyesi", 3. Bilgi Ekonomi ve Yönetim Kongresi, Osmangazi Üniversitesi, 2526 Kasim: 13-20.

Education at A Glance 2004, http:/ /www.oecd.org/edu/eag2004

Education at A Glance 2007, http:/ /www.oecd.org/edu/eag2007

Education at A Glance 2008, http:/ /www.oecd.org/edu/eag2008

Eriş, F. (2005), "Eğitimin Sosyal Faydaları: Türkiye-AB Karşılaştırması", Millî Eğitim, Yaz Y1l 33: say1 167, http: / / yayim.meb.gov.tr/dergiler/167/index3-eres.htm.

Göçer K. ve Çıracı H. (2003), “Türkiye'de Kentlerin Sosyal ve Ekonomik Göstergeleri Arasındaki İlişki", İTÜ Dergisi / A Mimarlık, Planlama, Tasarım Cilt:2, Say1:1, Mart: 3-14.

Günsoy, G. (2005), “İnsani Gelişme Kavramı ve Sağlıklı Yaşam Hakkı", ZKÜ Sosyal Bilimler Dergisi, Cilt 1, Sayı 2: 35-52.

http:/ /dx.doi.org/10.1787/467300445456

http:/ / dx.doi.org/10.1787/467310041335

http:/ / dx.doi.org/10.1787/468064465655

http://hdr.undp.org/

http:/ / hdrstats.undp.org/countries/country_fact_sheets/cty_fs_tur.html

http:/ /stats.oecd.org/wbos/Index.aspx?datasetcode $=$ health

http://www.oecd.org

http://www.who.int/Whosis/data
Kar, M. ve Taban S. (2005), "Human Capital Accumulation Policy in Turkey in the Eve of the EU Accession", Conference on Medium Term Economic Assessment, "Labour Market Transformation Towards KnowledgeBased Economy", Agency for Economic Analysis and Forecasting, 29-30 September, Sofya, Bulgaristan.

Kurul Tural, N., Eğitimin Finansmanı, Anı Yayınc1lık, Ankara, 2002.

Mayer D. (2000), "On the Role of Health in the Economic and Demographic Dynamics of Brazil, 1980-1995", Paper presented at the conference: "Population Dynamics and the Macro Economy" organized by Harvard Center for Population and Development Studies and IFS. September.

Mazgit, İ. (2002), “Bilgi Toplumu ve Sağlı̆̆ın Artan Önemi", I. Ulusal Bilgi, Ekonomi ve Yönetim Kongresi, Kocaeli Üniversitesi: $405-415$.

Mincer, J. (1991), "Education and Unemployment", NBER Economic Paper Series; No: 3838.

Nasir, Z.M. ve Nazli H. (2000) “Education And Earnings in Pakistan", Pakistan Institute of Development Economics, Research Report No. 177, http://www.pide.org.pk/Research/Re port177

OECD Health Data 2008, OECD, Paris, http://www.oecd.org

OECD in Figures 2008, http:/ / www.oecd.org

Saxton, J. (2000), "Investment in Education: Private and Public Returns", Joint Economic Comittee United States Congress, http://www.house.gov/jec/ 
Saygıll, Ş., Cihan, C. ve Yavan, Z.A. (2005), "Eğitim ve Büyüme", Türkiye İçin Sürdürülebilir Büyüme Stratejileri Konferansı Tartışma Tebliğleri, TÜSİAD-KOÇ, İstanbul, Haziran.

Schultz, T.W. (1968), "Education and Economic Growth: Return to Education" Readings in the Economics of Education,. UNESCO: 277-292.

Schultz, T.W. (1971), Investment in Human Capital, The Free Pres, New York.

Schultz, T.W. (1972), “Human Capital: Policy Issues and Research Opportunities", Chapter in NBER book Economic Research: Retrospect and Prospect Vol 6: Human Resources: 1-84.

Suhrcke M., ve Diğ. (2006), "The contribution of health to the economy in the European Union", Public Health, Vol. 120, No. 11: 994-1001.

Taban, S. (2006), “Türkiye'de Sağllk ve Ekonomik Büyüme Arasındaki Nedensellik İlişkisi, Sosyo Ekonomi, Temmuz-Aralik: 32-46.

UNDP Human Development Report, 2001, http://hdr.undp.org/

UNDP Human Development Report, 2003, http://hdr.undp.org/

UNDP Human Development Report, 2004, http://hdr.undp.org/

UNDP Human Development Report, 2005, http://hdr.undp.org/

UNDP Human Development Report, 2006, http://hdr.undp.org/

UNDP Human Development Report, 2007/200, http://hdr.undp.org/

Ünal, I. (1992), “Eğitim ve Gelir İlişkisi”, Ankara Üniversitesi Eğitim Bilimleri Fakültesi Dergisi Cilt 25, Sayı.1: 113-129.
Vorkink, A. (2005), “Türkiye'de Eğitim Reformu", December, http://www.worldbank.org.tr

Webber, J.D. (2002), "Policies to Stimulate Growth: Should We Invest in Health or Education?", Applied Economics, Vol.34: 1633-1643.

Weil, D.N. (2007), "Accounting for The Effect of Health on Economic Growth", The Quarterly Journal of Economics, MIT Press, Vol: 122 (3): 1265-1306. 